\title{
PESONA KERAMIK DALAM BUSANA ART WEAR DENGAN APLIKASI MOTIF BATIK CEPLOK
}

\author{
Santa Citra Cendana *)
}

\begin{abstract}
The passion of fashion stimulates the writer to create ceramic fashion art wear. By examining the latest fashion and following fashion event, the writer has anidea to combine clothes and ceramic.

Data collection method which is used by the writer is observation and library research. This creation is based on three step of creating handcrafted art which has practical function. The first step is braind storming (brainstorming of the idea, concept, and background of a creation), designing (making the design of ideas), creating (the realization of creation). Ceramic fashion art will come as an innovation in the ceramic industry.

The result of this creation is a handcrafted ceramic in a various forms andcolors which is hoped to be well accepted by society. This final assignment is afunctional ceramic creation. All of the ceramic fashion creation can be worn in some occasion.

Key words: ceramic, fashion, art wear, Ceplok
\end{abstract}

\section{INTISARI}

Menciptakan karya dengan sumber inspirasi Badak Jawa didasari atas ketertarikan penulis terhadap binatang badak khususnya badak Jawa. Badak Jawa memiliki keunikan tersendiri dari badak lainnya dan fenomena kepunahan yang terjadi saat ini seperti bentuk fisik kulit badak yang belipat seperti membentuk baju baja, cula, dan tergolong hewan yang hampir punah sehingga penulis tertarik untuk menciptakan sebuah karya seni kriya logam bertemakan badak Jawa ke dalam tugas akhir ini sekaligus sebagai syarat menyelesaikan studi S1 jurusan kriya

Metode pendekatan yang digunakan adalah ekspresi, kontemplasi, estetis, kemudian metode pengumpulan data dilakukan dengan studi pustaka dan observasi. Proses penciptaan karya seni ini memalui tiga tahapan yaitu, eksplorasi, perancangan, dan perwujudan. Karya logam yang disajikan dalam Tugas Akhir ini merupakan karya figuratif dan dikembangkan objeknya yang merupakan hasil dari perwujudan badak Jawa.

Hasil karya ini adalah seni kriya logam tiga dimensi dengan bentuk badak Jawa sebagai inspirasi dari penciptaan seni kriya dan memiliki pengembangan bentuk yang sedemikian rupa. Diharapkan karya ini dapat berkomunikasi dengan masyarakat secara baik. Karya seni kriya logam ini dibuat bukan dimaksudkan untuk mencari solusi ataupun menyelesaikan masalah, tetapi merupakan sebuah sentuhan ekspresi dan sarana penyampaian ide pribadi yang disampaikan kepada penikmat seni pada khususnya dan masyarakat pada umumnya.

Kata kunci: Badak Jawa, Seni kriya, Kriya logam

*) Santa Citra Cendana, Mahasiswa Program Studi S-1 Kriya Seni Jurusan Kriya, Fakultas Seni Rupa, Institut Seni Indonesia Yogyakarta. 


\section{PENDAHULUAN}

\section{Latar Belakang Penciptaan}

Era saat ini transaksi dengan media online yang kerap disebut online shop sedang marak di kalangan masyarakat. Setiap kali online selalu muncul iklan-iklan busana yang di dalamnya, mulai dari gaun, gamis, rok, celana, jaket, kemeja, dan masih banyak lagi. Walaupun yang dijual beragam bentuk dan jenisnya, semua memiliki kesamaan, yakni sama-sama menggunakan media kain. Di era modern saat ini semua orang selalu ingin tampil menarik. Oleh karena itu, wanitaselalu memperhatikan penampilannya atau biasa disebut dengan fashionable.

Hampir semua orang terutama wanita selalu memperhatikan masalah penampilan ketika sedang bepergian atau mendatangi acara-acara tertentu. Ingin tampil sempurna dan terlihat menarik saat di hadapan banyak orang adalah hal yang sangat wajar yang sering dilakukan oleh para wanita. Kebutuhan fashion seolah menjadi kebutuhan utama, apalagi dengan perkembangan zaman yang semakin maju dengan teknologinya mampu menciptakan barang-barang fashionable yang kerap dicari oleh wanita, misalnya saja sepatu, tas, baju, dan aksesoris yang sangat beragam bentuknya.

Tidak hanya sebatas busana casual yang dipakai sehari-hari, namun busanabusana art wear juga kerap digandrungi para wanita. Busana art wear itu sendiri merupakan busana yang rancangannya lebih menonjolkan aspek estetika dibandingkan dengan fungsionalnya dan diproduksi secara manual serta dilakukan dengan pengerjaan tangan bukan mesin. Dari sinilah muncul suatu ide, untuk mengolaborasikan busana art wear dengan keramik, karena penulis melihat busanabusana yang dijual baik di toko-toko, pusat perbelanjaan, maupun online shop tidak ada atau belum ada yang menggunakan media keramik. Selain itu harga bahan mentahnya juga terjangkau dan mudah dicari.

Berbicara masalah fashion banyak sekali bentuk, ukuran, dan motif. Pada perkembangan dunia fashion saat ini salah satunya adalah batik yang cukup diminati oleh banyak orang. Pada kesempatan ini penulis ingin menggabungkan motif batik Ceplok ke dalam busana art wear. Alasan penggunaan motif Ceplok dalam karya ini, karena motif Ceplok lebih beragam bentuknya. Ceplok merupakan kategori ragam hias berdasarkan pengulangan bentuk geometri, seperti segi empat, persegi panjang, dan bulat telur.

Dari beberapa alasan di atas, penulis ingin memberikan wacana baru melalui media busana yang kemudian diaplikasikan dengan keramik. Tentu penciptaan busana keramik ini sangat menarik, karena belum banyak orang yang mengerti bahwa keramik bisa difungsikan ke dalam busana khususnya busana art wear. Karya yang dibuat juga memiliki keunikan dan mempunyai ciri khas tersendiri.

\section{Hasil dan Pembahasan}

Menurut Riyanto (2003: 5) mengatakan bahwa busana merupakan kebutuhan pokok manusia dalam manusia berbudaya. Busana adalah segala sesuatu yang kita kenakan pada tubuh dengan maksud untuk melindungi tubuh maupun memperindah penampilan. Sedangkan 
menurut Bernard (2009: 24), Busana dibagi menjadi dua yaitu busana baku atau yang disebut anti-fashion, dan busana modis atau disebut fashion. Busana baku atau anti-fashion adalah busana yang menitikberatkan pada suatu kesamaan dan cenderung tetap atau tidak berubah. Sedangkan busana modis atau fashion adalah busana yang cenderung berganti mengikuti perkembangan zaman dan tren yang ada.

Menurut Charles Scribne's Sons (2005:12), Fashion digambarkan sebagai konstruksi budaya yang beridentitas. Diantaranya meliputi semua bentuk pakaian, termasuk gaya berpakaian, dan yang disebut fashion kelas atas yang diciptakan oleh para perancang busana dan penjahit pakaian. Fashion juga berkaitan dengan cara yang digunakan; untuk beberapa, fashion merupakan sesuatu yang dibuat ke dalam wujud tertentu. Paling umum, fashion digambarkan sebagai gaya pakaian atau tingkah laku dari waktu ke waktu, pakaian yang berkaitan erat dengan fisik tubuh dan identitas pribadi seseorang.

Pada penciptaan karya ini, penulis menciptakan busana yang termasuk dalam golongan art wear, dimana busana yang diciptakan hanya dapat digunakan pada waktu-waktu tertentu. Busana art wear itu sendiri merupakan busana yang rancangannya lebih menonjolkan aspek estetika dibandingkan dengan fungsionalnya dan diproduksi secara manual serta dilakukan dengan pengerjaan tangan bukan mesin.

\section{Proses perwujudan}

Proses perwujudan sebuah karya seni membutuhkan ide maupun gagasan yang segar juga diiringi dengan penguasaan material yang akan digunakan. Langkah ini diawali dengan pembuatan sketsa yang dikonsultasikan dengan dosen pembimbing sebagai pertimbangan dalam perwujudannya, namun pada praktiknya penguasaan teknik belumlah cukup untuk menentukan keberhasilan karya, mempersiapkan fisik dan ketenangan pikiran juga perlu diperhatikan. Hal ini sangat berpengaruh dalam keberhasilan sebuah karya yang akan diwujudkan nantinya. Pembuatan karya seni khususnya kriya sangat dipengaruhi oleh ide dan teknik.

Bahan yang digunakan dalam perwujudan karya ini adalah tanah liat Sukabumi dan tanah abu-abu(tanah model). Selain bahan baku tanah liat, ada beberapa bahan glasir yang digunakan dalam perwujudan karya diantaranya sebagai berikut: 1) Silika berfungsi sebagai unsur penggelas atau pelapis dari barang keramik; 2) Felspad untuk membantu peleburan bahan glasir terutama dalam proses pelelehan supaya lelehan sempurna menutupi bodi tanah liat keramik di waktu pembakaran glasir; 3) Kaolin membantu dalam pengerasan pada glasir dan menambah tinggi suhu glasir.

$$
\text { Peralatan didalam proses }
$$
pengerjaan penciptaan karya keramik ini kebanyakan menggunakan peralatan manual, yang sesuai dengan kebutuhan. Alat yang digunakan diantaranya adalah: butsir kawat, butsir kayu, sapatula tools, spon, kawat tembaga, gunting, benang, jarum, dan satu paket alat penjepit.

Teknik yang dilakukan dalam pengerjaan karya ini menggunakan teknik cetak padat. Cetak padat merupakan salah 
satu teknik pembuatan karya seni keramik, yaitu dengan menekan- nekan tanah liat ke dalam cetakan kemudian diangkat. Cetakan yang dimaksud adalah cetakan dari gipsum yang terbentuk dari hasil pencetakan model. Model adalah sebuah karya master, terbuat dari tanah liat abu-abu yang dibentuk sesuai dengan sketsa atau sesuai keinginan bentuk, dan nantinya akan dicetak dengan gipsum untuk memperbanyak produksi.

Setelah pembuatan model selesai dilakukan, langkah selanjutnya adalah mencetak model tersebut dengan menggunakan gipsum yang nantinya akan digunakan sebagai master dalam pembuatan kepingan-kepingan keramik. Pembuatan cetakan ini berfungsi untuk mempercepat proses produksi yang akan dilakukan pada tahan selanjutnya.

\section{Tahap Perwujudan}

a. Pembuatan Sketsa Motif Ceplok

Pembuatan sketsa ini dilakukan secara manual, menggunakan pensil kemudian diwarnai. Pembuatan sketsa harus disesuaikan dengan bentuk busana yang diinginkan, agar mempermudah dalam proses perangkaiannya nanti. Dalam pembuatan sketsa motif Ceplok, ukuran dan ketebalan juga dipertimbangkan agar tidak terlalu tebal pada saat divisualisasikan dengan media tanah liat.

b. Pembuatan Sketsa Busana

Pembuatan sketsa busana dilakukan secara manual, dengan mempertimbangkan letak rangkaian keramik yang nantinya akan dipasang. Bentuk busana harus mempertimbangkan kenyamanan pada saat dipakai, serta letak rangkaian harus benar-benar dipertimbangkan dengan detail.

c. Pembuatan Model

Model terbuat dari tanah abu-abu yang dibentuk sesuai sketsa motif Ceplok yang dibuat pada tahap pertama. Pembuatan model ini dilakukan manual dengan menggunakan butsir atau alat dekorasi keramik. Model ini berfungsi sebagai master yang nantinya akan dibuat cetakan untuk mempercepat proses produksi.

d. Pencetakan Model

Tahap pencetakan model harus dilakukan dengan cepat, karena gipsum cepat mengeras apabila sudah dalam bentuk adonan. Sebelum gipsum dituangkan di atas model, terlebih dahulu model ditata di atas papan triplek dan di batasi juga dengan triplek agar gipsum tidak keluar dan tercetak dengan rapi.

e. Pengeringan Cetakan

Proses pengeringan cetakan dilakukan secara manual, dengan dijemur di bawah sinar matahari dan dianginanginkan. Oleh sebab itu, pengeringan cetakan membutuhkan waktu sedikit lama. Pengeringan dilakukan secara manual agar cetakan dapat kering dengan sempurna, karena bila cetakan dipaksakan kering dengan cepat akan terjadi kerapuhan pada cetakan.

f. Penyempurnaan Cetakan

Penyempurnaan cetakan dilakukan untuk memperjelas detail-detail yang tidak bisa dicapai pada proses pembuatan model. Oleh karena itu, penyempurnaan model dilakukan ketika cetakan sudah mengering. Proses ini harus dilakukan dengan teliti, karena apabila gipsum tidak rapi maka hasil cetakan juga tidak akan maksimal. 
g. Pencetakan

Proses pencetakan tanah liat dilakukan dengan teknik cetak tekan atau cetak padat. Pada proses pencetakan ini tanah liat harus ditekan kedalam cetakan hingga padat dan tidak ada rongga di dalam, karena bila masih ada rongga maka udara akan masuk dan bisa rusak pada saat proses pembakaran. Setelah tanah liat selesai dicetak, tanah liat dirapikan dengan menggunaan sapatula tools agar permukaannya datar dan mudah pada saat proses pelepasan cetakan.

h. Pelepasan Hasil Cetakan

Pelepasan hasil cetakan dilakukan dengan menggunakan tanah liat yang sama, dengan cara tanah liat dibentuk menyerupai bola kecil. Kemudian menempelkannya di atas cetakan lalu ditarik ke atas pelan-pelan, agar tidak merusak bentuk cetakan.

\section{i. Penyempurnaan Detail dari Hasil Cetakan}

Tahap penyempurnaan detail ini membutuhkan ketelitian, karena ukuran yang sangat kecil dan riskan patah. Penyempurnaan detail dilakukan manual menggunakan alat dekorasi dengan menyesuaikan kebutuhan.

j. Pembuatan Lubang pada Keramik yang Masih Basah

Proses berikutnya adalah pembutan lubang pada keramik yang masih dalam keadaan setengah basah. Cara melubangi keramik ini dengan menggunakan besi yang berukuran sangat kecil, pembuatan lubang ini bertujuan untuk tempat benang atau rantai besi pada saat pemasangan.

k. Pengeringan Hasil Cetakan
Cetakan yang sudah dirapikan akan dikeringkan dengan cara diangin-anginkan, agar kering dengan sendrinya. Karena apabila dipaksakan untuk kering dengan cepat, keramik bisa retak dan akan pecah pada saat pembakaran. Cetakan juga harus diletakkan pada alas yang datar, agar permukaan keramik tidak melengkung pada saat proses pengeringan berlangsung.

I. Pewarnaan Glasir

Proses pewarnaan glasir pada pembuatan karya ini dilakukan dengan teknik kuas. Dalam proses mengglasir harus teliti dan hati-hati, karena harus sesuai area yang ingin diwarna. Glasir tidak boleh terlalu tipis dan terlalu tebal, jika terlalu tipis, glasir tidak akan muncul, dan jika terlalu tebal, tekstur keramik akan tertutup oleh glasir.

m. Proses Penataan Keramik dalam Tungku Pembakaran

Proses penataan keramik ke dalam tungku harus dilakukan dengan hati-hati, karena apabila salah dalam meletakkan posisi akan terjadi hal yang tidak diinginkan seperti perbedaan warna, keretakan, serta pecah.

n. Perangkaian Kepingan Keramik

Setelah keramik melalui proses pembakaran, keramik siap untuk dirangkai sesuai sketsa yang dibuat. Dalam proses ini kepingan-kepingan keramik dirangkai dengan benang dan juga rantai besi. Rangkaian keramik harus benar - benar diperhitungkan jumlah dan posisinya, agar ketika disusun bisa mendapatkan hasil yang sesuai dengan sketsa.

o. Proses Penempelan Keramik dengan Teknik Jahit

Selain merangkai kepingan keramik dengan benang dan rantai besi, ada 
beberapa model busana yang menggunakan teknik jahit. Proses ini juga dilakukan manual atau jahit tangan, karena penempelan keramik harus dijahit satu per satu. Penempelan keramik dengan teknik jahit harus dilakukan dengan teliti, agar keramik tidak mudah lepas pada saat digunakan.

\section{Tinjauan karya}

Penciptaan ini menghasilkan busana art wear dengan aplikasi motif batik Ceplok. Ada beberapa motif batik Ceplok yang digunakan sebagai acuan dalam pembuatan karya ini, diantaranya adalah Ceplok Larasati, Ceplok Blebar, Ceplok Mlati, dan Ceplok Cokrokusumo. Motif batik Ceplok yang sudah terpilih akan dieksplorasi ke dalam beberapa bentuk agar dapat dirangkai. Pembuatan karya ini menggunakan beberapa teknik, yaitu teknik slab dan cetak padat.

Setiap karya yang diciptakan memiliki arti filosofi masing-masing, sesuai motif batik yang digunakan. Karya terdiri atas bermacam-macam bentuk seperti perpaduan antara bustier dengan rok pendek, bustier dengan celana pendek, bustier dengan rok lingkar, bustier dengan rok span, dan bustier dengan rok tulip.

Kain yang digunakan dalam penciptaan karya ini berwarna, karena warna hitam bersifat netral dan membuat keramik terlihat dengan jelas. Pengaplikasian kepingan- kepingan keramik dirangkai menggunakan rantai besi dan tali benang. Namun ada juga beberapa kepingan keramik yang ditempelkan dengan cara dijahitkan pada busana.
Hasil Karya

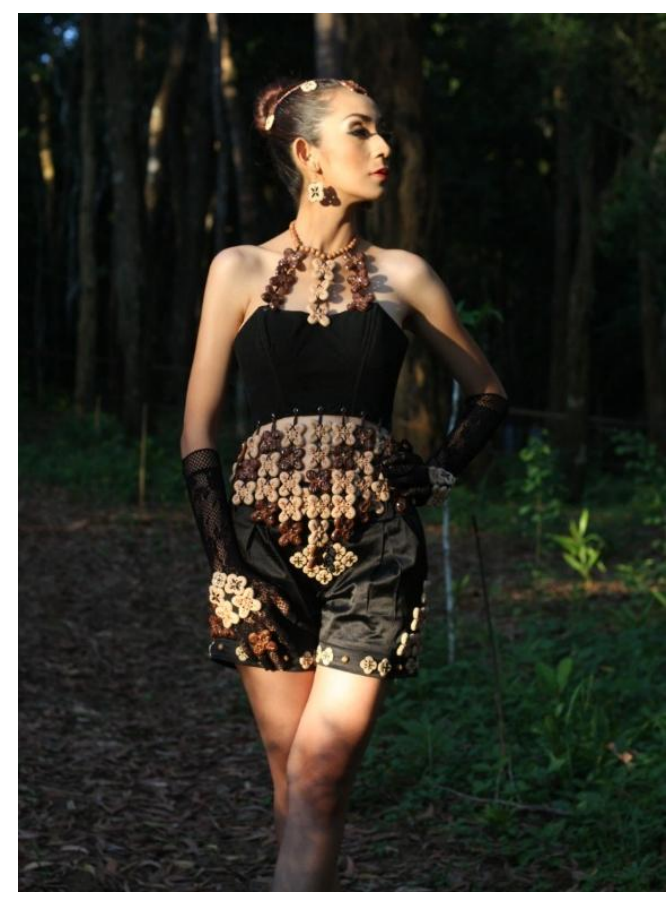

Gambar 1. Karya 1

Judul: Pesona Keramik \#1

Media: Keramik, Kain Bludru, Kain Renda, dan Benang Rajut, Tahun pembuatan: 2015

Ukuran: Standar, Fotografer: Ea Setiawan \& Eko Model: Devi

Konsep karya :

Busana keramik art wear ini menggunakan aplikasi motif batik Ceplok Kawung Brendi. Motif batik ini memiliki makna semangat yang harus terus ditularkan. Pemakai motif batik ini diharapkan mampu memberikan semangat kehidupan pada orang - orang disekitarnya. 


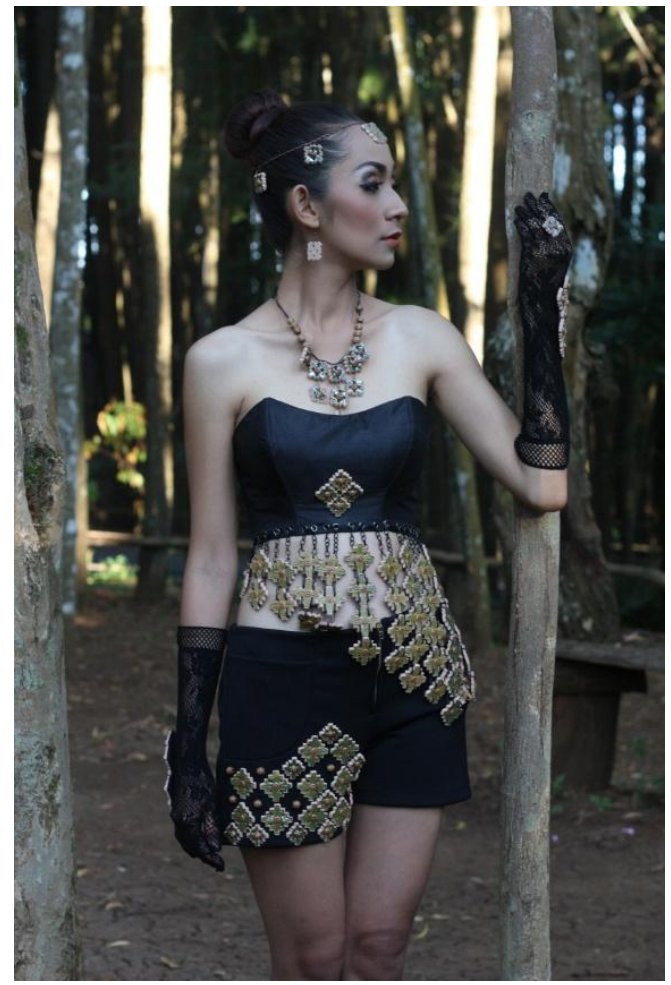

Gambar 2. Karya 2

Judul: Pesona Keramik \#2

Media: Keramik, Kain Taisilk, Kain Renda, dan Rantai Besi, Tahun pembuatan: 2015

Ukuran: Standar

Fotografer: Ea Setiawan \& Eko

Model: Devi

Konsep karya:

Busana art wear ini menggunakan aplikasi motif batik Ceplok Larasati. Motif batik ini memiliki makna keselarasan. Pemakai motif batik ini diharapkan mampu menjadi pribadi yang menjaga keselarasan sesame manusia dan alam sekitarnya.

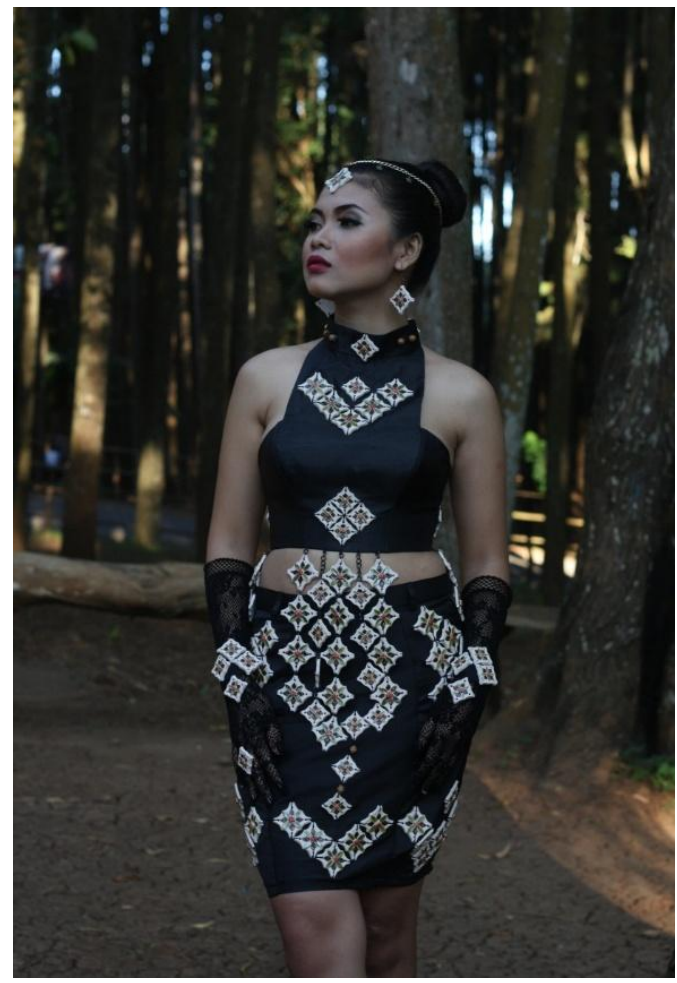

Gambar 3. Karya 3

Judul: Pesona Keramik \#3

Media: Keramik, Kain Taisilk, Kain Renda, dan Rantai Besi, Tahun pembuatan: 2015

Ukuran: Standar

Fotografer: Ea Setiawan \& Eko Model: Ayu

\section{Konsep karya:}

Busana art wear ini menggunakan aplikasi motif batik Ceplok Wahyu Ningrat. Pemakai motif batik tersebut diharapkan selalu dalam kecukupan dan kebahagiaan, sehingga dapat menyejahterakan orangorang yang ada di lingkungan sekitarnya.

\section{Penutup}

Demikian karya-karya ini diciptakan dengan proses dan tahap pengerjaan yang sangat panjang dari awal hingga akhir. Beberapa permasalahan muncul saat proses pengerjaan berlangsung antara lain: saat proses pembuatan model, sangat sulit mencapai detail terkecil. Pembuatan ratusan kepingan yang dilakukan secara 
manual membutuhkan kesabaran dan ketelitian. Pewarnaan yang sedikit sulit karena objek keramik terlalu kecil, sehingga hanya dapat dicapai dengan kuas yang berukuran sangat kecil. Selain itu pada saat pembakaran berlangsung, ada beberapa keping keramik yang mengalami keretakan. Tidak hanya itu, kendala juga terjadi pada saat proses perangkaian keramik, dikarenakan bahan yang tidak elsatis sehingga rangkaian harus benar-benar diperhatikan bentuk dan kerapiannya. Proses pengerjaan yang panjang dan waktu yang sangat singkat menjadikan tantangan tersendiri dalam proses penyelesaian tugas akhir ini.

Adanya solusi-solusi saat berlangsungnya proses pengerjaan pada akhirnya semua permasalahan selesai dengan hasil yang cukup memuaskan. Akan tetapi dengan proses yang telah dilakukan, pastilah ada beberapa kekurangan dan dengan adanya saran, masukan, serta tambahan ilmu, maka hal tersebut akan dapat menjadi pertimbangan dalam proses berkarya selanjutnya.

\section{DAFTAR PUSTAKA}

Astuti, Ambar. (2008a), Keramik, Bahan, Cara Pengerjaan, Gelasir, Arindo Nusa Media, Yogyakarta.

. (2008b), Keramik IImu dan Proses pembuatannya, Arindo Nusa Media, Yogyakarta.

Bernard, Malcom. (2009), Fashion Sebagai Komunikasi, Jalasutra, Yogyakarta.

Charles Scribne's Sons.(2005), Encyclopedia of Clothing and Fashion Vol.2,Imprint Thomapson Gale.
Departemen Perindustrian R.I. (1983/1984), Kumpulan Motif Batik, Departemen Perindustrian R.I Badan Penelitian dan Pengembangan Industri Balai Besar Penelitian dan Pengembangan Industri Kerajinan dan Batik Proyek Balai Pengembangan dan Penelitian Batik, Yogyakarta.

Gustami, Sp. (2004), "Proses Penciptaan Seni Kriya: Untaian Metodologis", Program Pasca Sarjana S2 Penciptaan dan Pengkajian Seni ISI Yogyakarta.

Hamidin, Aep S. (2010), Batik Warisan Budaya Asli Indonesia, Narasi, Yogyakarta.

Industrial Research and Development Ministri of Industry. (2009), Batik, the Image of Indonesian Tradition and Heritage, Ministry of Industrial Development and Research Division Central Agency of Handicraft and Batik, Yogyakarta.

Kartika, Dharsono Sony. (2004a), Seni Rupa Modern, Rekayasa Sains, Bandung.

Pengantar Estetika,
$\begin{aligned} & \text { Bandung. } \\ & \text { Rekayasa }\end{aligned}$

Mudjiono dan B. Irawan.(2008), Asas dan Unsur Desain, Universitas Kristen Petra Fakultas Seni dan Desain Jurusan Desain Komunikasi Visual, Surabaya.

Musman, Asti dan Ambar B. Arini. (2011), Batik Warisan Adiluhung Nusantara, Andi Offset, Yogyakarta.

Nurmianto, Eko. (2003), Ergonomi Dasar dan Aplikasinya, Guna Widya, Surabaya. 
Poerwadarminta, W.J.S. (2002), Kamus Umum Bahasa Indonesia, Balai Pustaka, Jakarta.

Riyanto, Arifah A. (2003), Teori Busana, Yapemdo, Bandung.

Sachari, Agus. (1986), Seni Desain dan Teknologi, Pura Pustaka, Jakarta.

Soesanto, Sewan. (1984), Seni dan Teknologi Kerajinan Batik, Departemen Pendidikan dan Kebudayaan Dirjen Pendidikan Dasar dan Menengah, Jakarta.

Sastrowinoto, Suyatno. (1985), Meningkatkan Produktivitas dengan Ergonomi, PT. Pustaka Binaman Pressindo, Jakarta. 